\title{
Factors influencing temporal changes in chemical composition of biogenic deposits in the middle Tążyna River Valley (Kuyavian Lakeland, central Poland)
}

\author{
Daniel Okupny ${ }^{1, *}$, Seweryn Rzepecki ${ }^{2}$, Ryszard Krzysztof Borówka ${ }^{3}$, Jacek \\ Forysiak $^{4}$, Juliusz Twardy ${ }^{4}$, Anna Fortuniak ${ }^{5} \&$ Julita Tomkowiak ${ }^{3}$
}

\author{
${ }^{1}$ Pedagogical University of Cracow, Institute of Geography, Podchorążych 2, 30-084 Kraków, Poland \\ ${ }^{2}$ University of Łódź, Archaeology Institute, Uniwersytecka 3, 90-137 Łódź, Poland \\ ${ }^{3}$ University of Szczecin, Geology and Palaeogeography Unit, Faculty of Geosciences, Mickiewicza 18, 70-383 Szczecin, \\ Poland \\ ${ }^{4}$ University of Łódź, Institute of Earth Science, Department of Geomorphology and Palaeogeography, Narutowicza 88, \\ 90-139 Łódź, Poland \\ ${ }^{5}$ University of Lódź, Institute of Earth Science, Laboratory of Geology, Narutowicza 88, 90-139 Łódź, Poland \\ *corresponding author: e-mail: daniel.okupny@up.krakow.pl
}

\begin{abstract}
The present paper discusses the influence of geochemical properties on biogenic deposits in the Wilkostowo mire near Torun, central Poland. The analysed core has allowed the documentation of environmental changes between the older part of the Atlantic Period and the present day (probably interrupted at the turn of the Meso- and Neoholocene). In order to reconstruct the main stages in the sedimentation of biogenic deposits, we have used stratigraphic variability of selected litho-geochemical elements (organic matter, calcium carbonate, biogenic and terrigenous silica, macro- and micro-elements: $\mathrm{Na}, \mathrm{K}, \mathrm{Mg}, \mathrm{Ca}, \mathrm{Fe}, \mathrm{Mn}, \mathrm{Cu}, \mathrm{Zn}, \mathrm{Pb}, \mathrm{Cr}$ and $\mathrm{Ni}$ ). The main litho-geochemical component is $\mathrm{CaCO}_{3}$; its content ranges from 4.1 per cent to 92 per cent. The variability of $\mathrm{CaCO}_{3}$ content reflects mainly changes in hydrological and geomorphological conditions within the catchment area. The effects of prehistoric anthropogenic activities in the catchment of the River Tążyna, e.g., the use of saline water for economic purposes, are recorded in a change from calcareous gyttja into detritus-calcareous gyttja sedimentation and an increased content of lithophilous elements (Na, $\mathrm{K}, \mathrm{Mg}$ and $\mathrm{Ni}$ ) in the sediments. Principal component analysis (PCA) has enabled the distinction the most important factors that affected the chemical composition of sediments at the Wilkostowo site, i.e., mechanical and chemical denudation processes in the catchment, changes in redox conditions, bioaccumulation of selected elements and human activity. Sediments of the Wilkostowo mire are located in the direct vicinity of an archaeological site, where traces of intensive settlement dating back to the Neolithic have been documented. The settlement phase is recorded both in lithology and geochemical properties of biogenic deposits which fill the reservoir formed at the bottom of the Parchania Canal Valley.
\end{abstract}

Keywords: lake sediments, peat, geochemistry, human activity, central Europe 


\section{Introduction}

Biogenic sediments constitute a kind of natural archive that makes it possible to track environmental changes that took place in antiquity (Cohen, 2003; Zolitschka et al., 2003; Chambers \& Charman, 2004). Such changes are driven not only by a range of natural processes but also by human influence (Kalis et al., 2003; Rösch \& Lechterbeck, 2016). Geochemical analysis is one of the research methods used for studying biogenic sediments. Gorham \& Swaine (1965), Mackereth (1965) and Jones \& Bowser (1978) all listed some of the factors that have an impact on the chemical composition of sediments that fill reservoirs of biogenic accumulation, namely the geological structure and lithology in the catchment of a basin, the source of the supply and the catchment of lake waters, the intensity of photosynthetic processes, the intensity of $\mathrm{CaCO}_{3}$ precipitation, the morphology of lake basins, the water balance of the lake, a change in the rate of denudation processes and changes in the vegetation cover, as well as land use in the catchment area. Due to increased human impact on the environment and also contamination of this with toxic substances (e.g., trace elements), the chemical composition of the biogenic sediments has become a matter of interest to many researchers (e.g., Birch et al., 1996; Tylmann, 2005; Fiałkiewicz-Kozieł et al., 2011; Pawłowski et al., 2015; Martínez Cortizas et al., 2016).

The aim of the present study was to investigate the distribution of litho-geochemical elements in the sediment of the peatbog at Wilkostowo (central Poland), the development of which took place in the Mesoholocene in relation to the creation of a lake in the River Tążyna Valley. The factors which might have an impact on the distribution of elements in limnic and peat deposits were recognised. In the context of increased human impact and environmental changes, the geochemical research corresponds with the results of a study of relief transformation in the mid-section catchment areas of the River Tążyna, which occurred during the Mesoand Neoholocene.

\section{Regional setting}

The study area is situated in the eastern part of the Kuyavian (Kujawy) Lakeland in the northwestern portion of the Inowrocław Plain (Krygowski, 1961) (Fig. 1A-B). From a geological point of view (Stupnicka, 1989), this area belongs to the Kuyavian-Pomeranian (central Polish) anticlinorium. Salt anticlines are located in the vicinity of Inowrocław, around $20 \mathrm{~km}$ west of the study area. Czerwiński (1996) and Hulisz (2007) recorded the frequent presence of salinity of waters and soils of the Kuyavian Lakeland. The use of saline springs hypothetically played a very important role in local stability of prehistoric occupation of the middle Tążyna River Valley. In relation to the discussed area, these springs were located within several hours' walk.

Altitudes in the study area range from $102.9 \mathrm{~m}$ a.s.l. in places where dunes covered the moraine plateaus to less than $70 \mathrm{~m}$ to the north of the study site, at the bottom of the Tążyna River Valley. The relief of the research area is relatively poorly undulated; the reason for that is that it was situated within the area of the last glacial cover. It consists of forms of glaciogenic (moraine plateaus), glaciofluvial and fluvial (glaciofluvial plains and the Tążyna and Parchania Canal valleys) and aeolian origin (aeolian plains and dunes). The glaciofluvial sands and gravels contain less than 10 per cent of $\mathrm{CaCO}_{3}$. Biogenic deposits are of great importance for the surface composition of the research area - they occur in the form of several patches of bogs and shallow, temporary reservoirs. A general description of the geological and geomorphological setting of the Tążyna River Valley and neighbouring areas was presented by Andrzejewski (1995), Weckwerth (2010) and Andrzejewski \& Weckwerth (2010). A set of closed depressions within the sandur came into existence as part of thermokarst-forming processes during the late Weichselian; however, depressions formed at the bottom of the Parchania Canal Valley had a different origin. While the formation of the lake basin at Przybranówek took place before the Allerød interstadial (Rzepecki et al., 2015), the palaeolake at Wilkostowo formed during the Mesoholocene when thermokarst-forming processes in the Polish Lowland had already ceased (compare e.g., Goździk, 1995; Błaszkiewicz, 2007). As has been revealed by works performed on the fossil base of the swamps, the depressions are relatively narrow and elongated and their origin can be linked to some sections of riverbeds (Fig. 1C). The peatbog at Wilkostowo is of irregular shape, its longitudinal axis being $210-220 \mathrm{~m}$ in length, the latitudinal 100-150 m. It occupies an area of nearly 3 hectares and is situated $300 \mathrm{~m}$ away from the centre of the Neolithic Age settlement.

The archaeological site at Wilkostowo was explored between 1999 and 2011 and the surveyed outcrops amounted to a total area of $10,120.5 \mathrm{~m}^{2}$. As a result of the excavation works, a total of 50,203 pottery fragments related to Trichterbecher culture (TRB) were recovered with a total weight of 433,669 g. Moreover, 16,624 lumps of daub (weight: 

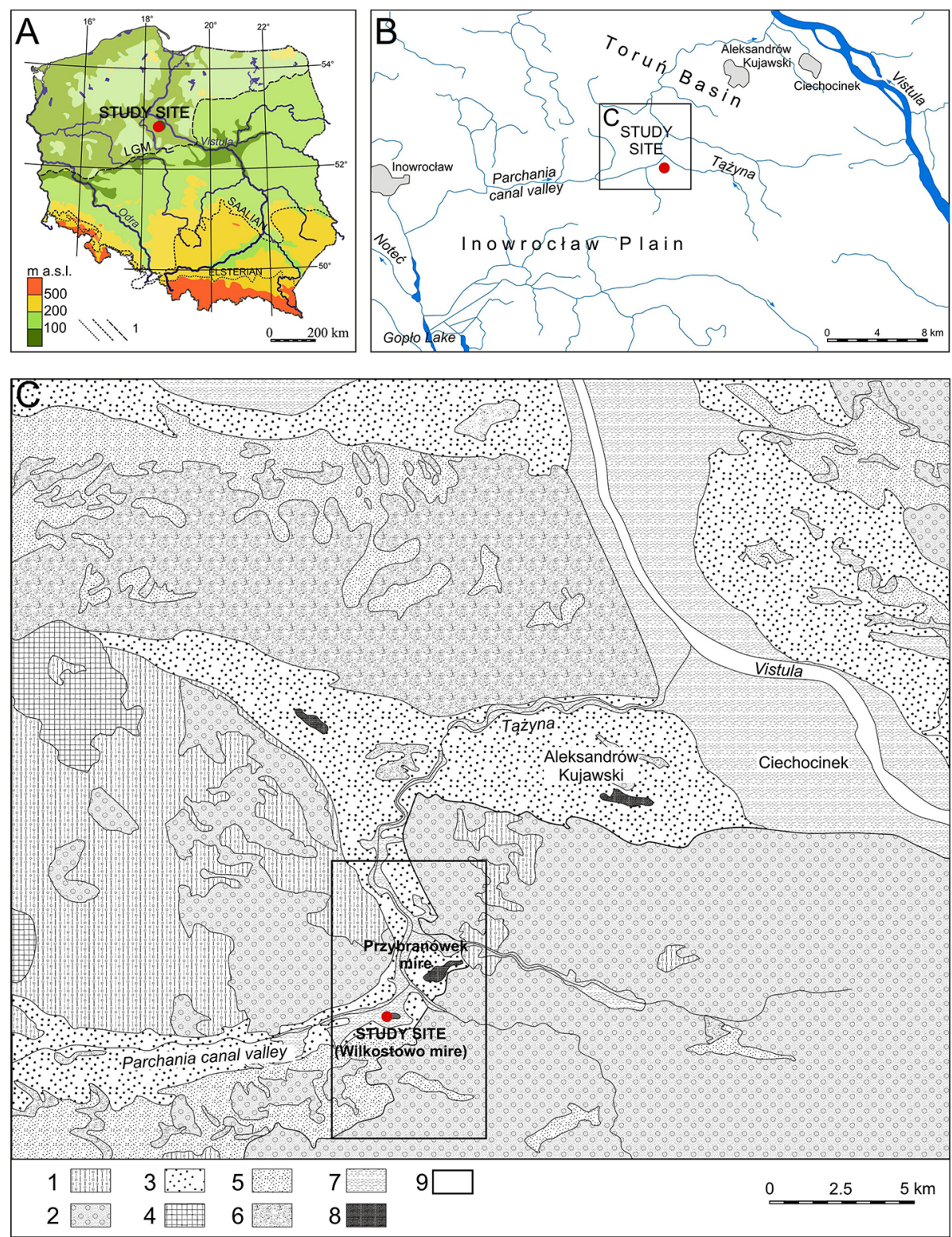

Fig. 1. A - Position of the Wilkostowo mire in Poland: 1 - Extent of ice sheets (after Marks, 2005); B - Position of the Wilkostowo mire against the river network of the Inowrocław Plain and neighbouring areas; C - Geological map of the area surrounding Wilkostowo (simplified after Niewiarowski et al., 1976).

Weichselian, Poznań Phase: 1- boulder clay; 2 - Ice Age sands and gravels; 3 - glaciofluvial sands (sandur); 4 - glaciolacustrine lake silts; Late Weichselian/Holocene: 5 - aeolian sands; 6 - aeolian sands in dunes; 7 - fluvial silts and sands; 8 - peats and humic muds; 9 - range of hydrological sketch map (see Fig. 2).

$106,685 \mathrm{~g}), 1,150$ flint artifacts, 467 stone artifacts and 4,071 fragments of animal bones were collected. These rich materials were connected with the existence of 12-15 houses, which probably were inhabited by c. $60-85$ people. It is worth noting that the site, most likely, existed in the period of 3,523-3,449 BC (Rzepecki, 2015). Generally, the occupation of the TRB culture was not located in wet floors of river valleys or on closed depressions that were too wet. However, an important charac- teristic of many TRB cultural sites is their location in a zone near the very edge of former swamps, mires and floodplains - at a distance of between 100 and $200 \mathrm{~m}$ from flowing water (Fig. 2).

\section{Material and methods}

One sediment core for palaeobotanical and geochemical studies was collected from the Wilkos- 

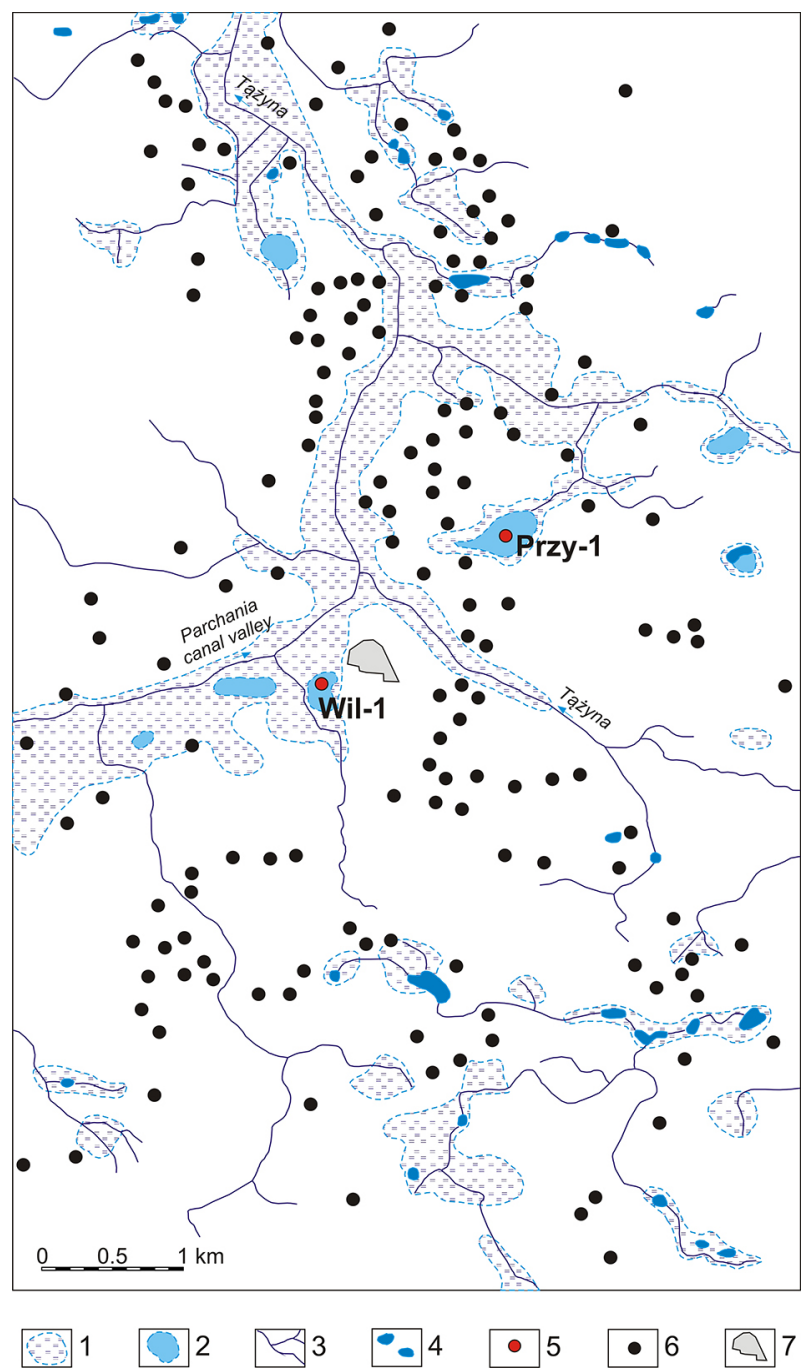

Fig. 2. Results of analysis of settlement dispersion of the TRB culture in relation to hydrological network. 1 - wetlands functioning in prehistory, 2 - outlines of lakes functioning in prehistory, 3 - river network, 4 - water bodies functioning today, 5 - location of the Wil-1 and Przy-1 cores, 6 - sites of TRB culture, 7 range of the archaeological site at Wilkostowo.

towo peatbog, where the thickest biogenic deposits were found (up to $220 \mathrm{~cm}$ ), in the deepest reservoir lying in the southern part of the Parchania Canal floodplain (Fig. 1C). The core Wil-1 (52 $48^{\prime} 27^{\prime \prime} \mathrm{N}$; $18^{\circ} 36^{\prime} 9^{\prime \prime}$ E), obtained with the use of the Instorf sampler, was divided in the laboratory into 2-cmlong sections, which yielded a total of 110 sediment samples. The basic litho-geochemical data for these samples were defined in accordance with the guidelines by Heiri et al. (2001) and Tobolski (2005) concerning the following: organic matter - OM (the loss on ignition method in a muffle furnace at $550^{\circ} \mathrm{C}$ for 4 hours), calcium carbonate $-\mathrm{CaCO}_{3}$ (the volumetric method using the Scheibler apparatus) as well as biogenic opal $\left(\mathrm{SiO}_{2 \text { biog }}\right)$ and terrigenous silica $\left(\mathrm{SiO}_{2 \text { ter }}\right)$. In the intermediate stage which preceded the determination of $\mathrm{SiO}_{2 \text { biog }}$ content, clean ash, obtained from raw ash by removing the components soluble in $\mathrm{HCl}$, underwent assay. The residue after acid treatment $\left(\mathrm{SiO}_{2 \text { tot }}\right)$ was separated by extraction of opal $\left(\mathrm{SiO}_{2 \text { biog }}\right)$ with $\mathrm{KOH}$ (Tobolski, 2005). The content of $\mathrm{SiO}_{2 \text { ter }}$ was calculated as $\mathrm{SiO}_{2 \text { ter }}$ (per cent) $=\mathrm{SiO}_{2 \text { tot }}-\mathrm{SiO}_{2 \text { biog. }}$. The determined ratios of these components were used for the classification of sediments recorded, following the procedure proposed by Markowski (1980). In addition, the $\mathrm{pH}$ values of sediments were recorded (the potentiometric method - the sample is dissolved in distilled water) and the degree of peat decomposition $(\mathrm{H})$ was estimated according to the scale published by von Post in 1924 (Aaby, 1986; Drzymulska, 2016). Furthermore, a detailed geochemical examination of 55 samples was performed (in order to determine the content of micro- and macro-elements). The ash after ignition, free of OM, was wet digested in a microwave digestion system, using concentrated $\mathrm{HNO}_{3}, 10$ per cent $\mathrm{HCl}$ and $\mathrm{H}_{2} \mathrm{O}_{2}$. The resulting solution was used to determine the concentration of the elements vital for palaeogeography: $\mathrm{Na}, \mathrm{K}, \mathrm{Ca}, \mathrm{Mg}, \mathrm{Fe}, \mathrm{Mn}$ and trace elements ( $\mathrm{Ni}, \mathrm{Cu}, \mathrm{Cr}, \mathrm{Pb}$ and $\mathrm{Zn}$ ), by the Atomic Absorption Spectrometry technique.

A stratigraphically constrained cluster analysis (using the method of incremental sum of squares) was applied to distinguish geochemical zones. This frequently used method is thought to be one of the best agglomeration techniques (Mangiamelli et al., 1996). In order to determine the variability of factors controlling the chemical composition of the deposits we used principal component analysis (PCA), which is one of the basic ordination techniques applied to data in palaeolimnology (Legendre \& Birks, 2012; Minyuk et al., 2014). This analysis was performed on a correlation matrix of major and trace elements (with the exception of $\mathrm{Pb}$ ) and $\mathrm{OM}, \mathrm{CaCO}_{3^{\prime}} \mathrm{pH}, \mathrm{SiO}_{2 \text { biog }}$ and $\mathrm{SiO}_{2 \text { ter }}$. To assign the same weight to all measurements, each variable in the original data set was standardised by subtracting its mean and dividing it by its standard deviation: $\mathrm{a}_{\mathrm{ij}}=\left(\mathrm{x}_{\mathrm{ij}}-\mathrm{x}_{\mathrm{j}}\right) / \sigma_{\mathrm{j}}$, where $\mathrm{a}_{\mathrm{ij}}$ is the value after standardisation, $x_{i j}$ is the value before standardization, $x_{i j}$ is the mean value of geochemical properties and $\sigma_{j}$ is the standard deviation. According to Xue et al. (2011) standardisation may amplify the noise associated with minor variables that may carry a relatively larger analytical error. The variability in conditions of sedimentation was estimated on the basis of the correlations of results of different measurements as was done by Walanus (2000). In the case of the Wil-1 core, the 
Table 1. Results of radiocarbon dating from the Wilkostowo mire (Wil-1 core).

\begin{tabular}{lcccl} 
Sample no. & Depth $(\mathrm{cm})$ & ${ }^{14}$ C age (a BP) & $\begin{array}{c}\text { Calibrated age }(95.40 \% \\
\text { probability) cal. a BP }\end{array}$ & Deposit \\
\hline MKL - 1224 & $215-210$ & $9860 \pm 100$ & 9141 & detritus-calcareous gyttja \\
MKL - 1278 & $141-137$ & $6950 \pm 90$ & 5673 & calcareous gyttja \\
MKL - 1279 & $95-92$ & $6020 \pm 90$ & 4796 & detritus-calcareous gyttja \\
\hline
\end{tabular}

[̂r] marker was calculated for 15 variables (geochemical properties) as a moving mean. The calculations were run using PAST version $2.17 \mathrm{c}$ software (Hammer et al., 2001).

The chronology of the accumulation of biogenic-carbonate deposits is based on the radiocarbon dating of the series of the deposit with a high content of organic remains. The radiocarbon dating, using the scintillation technique, was carried out in the Laboratory of Absolute Dating at Skała near Kraków, Poland (MKL signature). The age was calculated for three samples (Table 1). Conventional radiocarbon dates were calibrated using $\mathrm{OxCal}$ 4.2.2 (Bronk Ramsey, 2009) and the IntCal13 calibration curve (Reimer et al., 2013). The attempt to perform a palynological analysis of the sediment core sampled at Wilkostowo showed its limited suitability for a palaeobotanical reconstruction (M. Obremska, pers. comm., 2014).

\section{Results and discussion}

\subsection{Relationship between chemical composition and lithology}

The concentration of most litho-geochemical components from the Wil-1 core corresponds to a range of lithologies (Fig. 3). Exceptions are contents of $\mathrm{Cu}, \mathrm{Pb}$ and $\mathrm{Mn}$. The $\mathrm{Ca}$ content reveals the strongest link to lithology. This element occurs mostly in the form of calcite in lake deposits (Jones \& Bowser, 1978; Schnurrenberger et al., 2003). Because of this, the highest values of Ca concentration were recorded within the lacustrine chalk and carbonate gyttja (nearly 30 times higher than in other sediment types) (Fig. 4A). However, a negative correlation between the content of $\mathrm{CaCO}_{3}$ and Fe (Fig. $4 \mathrm{~B})$ records sedimentation processes typical of the deepest parts of a lake. Intensive photosynthetic activity of plankton leads to rapid exhaustion of $\mathrm{CO}_{2}$ dissolved in lake water and its simultaneous oxygenation. Under such conditions, a reduction and dissolution of Fe compounds is observed, together with precipitation of sparingly soluble carbonates, which gradually sink to the bottom of the reser- voir. The $\mathrm{CaCO}_{3}$ content ranges from 4.1 per cent in the herbaceous peat to 92 per cent in the lacustrine chalk. The high $\mathrm{CaCO}_{3}$ content in sediments studied indicates the long-term persistence of high water supersaturation with respect to calcite in the reservoir. Yet, data for carbonate deposits reveal a very low content of other components (mainly $\mathrm{SiO}_{\text {2biog' }} \mathrm{K}$, Fe and $\mathrm{Zn}$ ).

Biogenic silica in sediments of the Wilkostowo reservoir indicates two periods of development (Fig. 3). In the middle part of the lacustrine sedimentary sequence (between 125 and $100 \mathrm{~cm}$ ) the maximum concentration of $\mathrm{SiO}_{2 \text { biog }}$ attains about 22 per cent. In the top part of the section, $\mathrm{SiO}_{2 \text { biog }}$ increases to 24 per cent. Culminations of $\mathrm{SiO}_{2 \text { biog }}$ correspond to a decrease of $\mathrm{CaCO}_{3}$ content and an increase of OM (Fig. 5A-B). No correlation between the content of $\mathrm{SiO}_{2 \text { biog }}$ and $\mathrm{SiO}_{2 \text { ter }}$ attests to a higher diatom productivity in periods of decreased denudation in the catchment (Fig. 5C). Such a situation allows to exclude an important role of accessibility of orthosilicate $\left(\mathrm{H}_{4} \mathrm{SiO}_{4}\right)$ for the development of diatoms in lakes (Woszczyk, 2011). The influence of changes in intensity of $\mathrm{CaCO}_{3}$ precipitation of on different degrees of dilution of other components was also found by Nowaczyk (2008) in lake deposits at the locality of Osłonki and by Apolinarska et al. (2012) in sediments taken from Lake Skrzynka.

The vertical variability of the Mn content was fundamentally different from other elements analysed (Fig. 3). The largest concentrations of this element were found in the lower and middle parts of the Wil-1 section. Within the part dominated by lacustrine chalk a sharp decline of Mn concentration was found. Manganese was in the first place in the group of the migrating elements (at a depth of 186-164 and 126-112 cm), which may indicate the superiority of the power of the river or surface water. River water is either rich in $\mathrm{Mn}^{2+}$ ions or acts as a transport medium for its colloidal suspension (Kabata-Pendias, 2011).

The vertical profiles of the $\mathrm{Cu}, \mathrm{Cr}$ and $\mathrm{Ni}$ content are characterised by considerable irregularity. Changes in concentrations of these elements neither correspond to the lithological type of sediments nor correlate with the content of other components (Ta- 

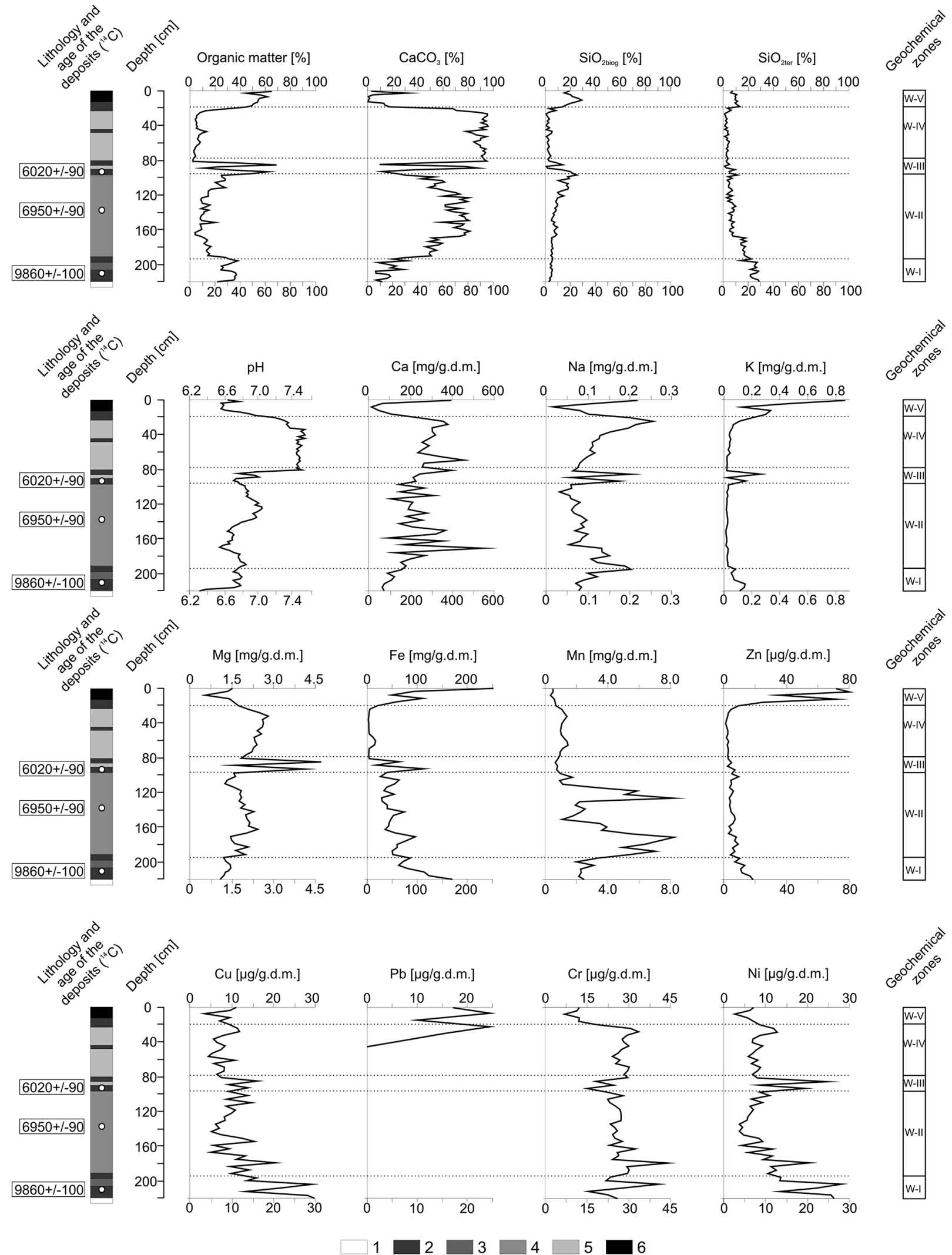

Fig. 3. Geochemical diagram and geochemical zones in sediments of the Wil-1 core.

1 - mineral (sands) deposits, 2 - detritus-calcareous gyttja, 3 - clay-calcareous gyttja, 4 - calcareous gyttja, 5 - lacustrine chalk, 6 - highly decomposed herbaceous peat. 

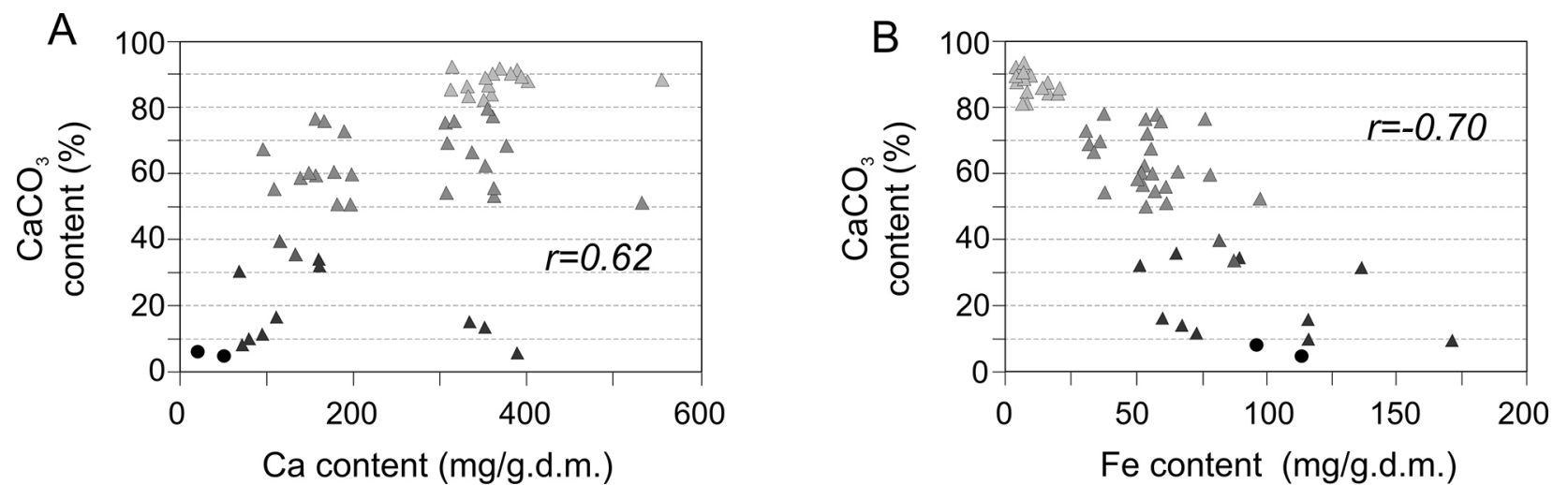

\section{$\triangle 1 \Delta 2 \Delta 3 \Delta 4 \quad 05$}

Fig. 4. Relationship between $\mathrm{CaCO}_{3}$ and $\mathrm{Ca}$ content (A) and $\mathrm{CaCO}_{3}$ and $\mathrm{Fe}$ content (B) within lake and peat deposits of the Wil-1 core.

1 - detritus-calcareous gyttja, 2 - clay-calcareous gyttja, 3 - calcareous gyttja, 4 - lacustrine chalk, 5 - highly decomposed herbaceous peat.
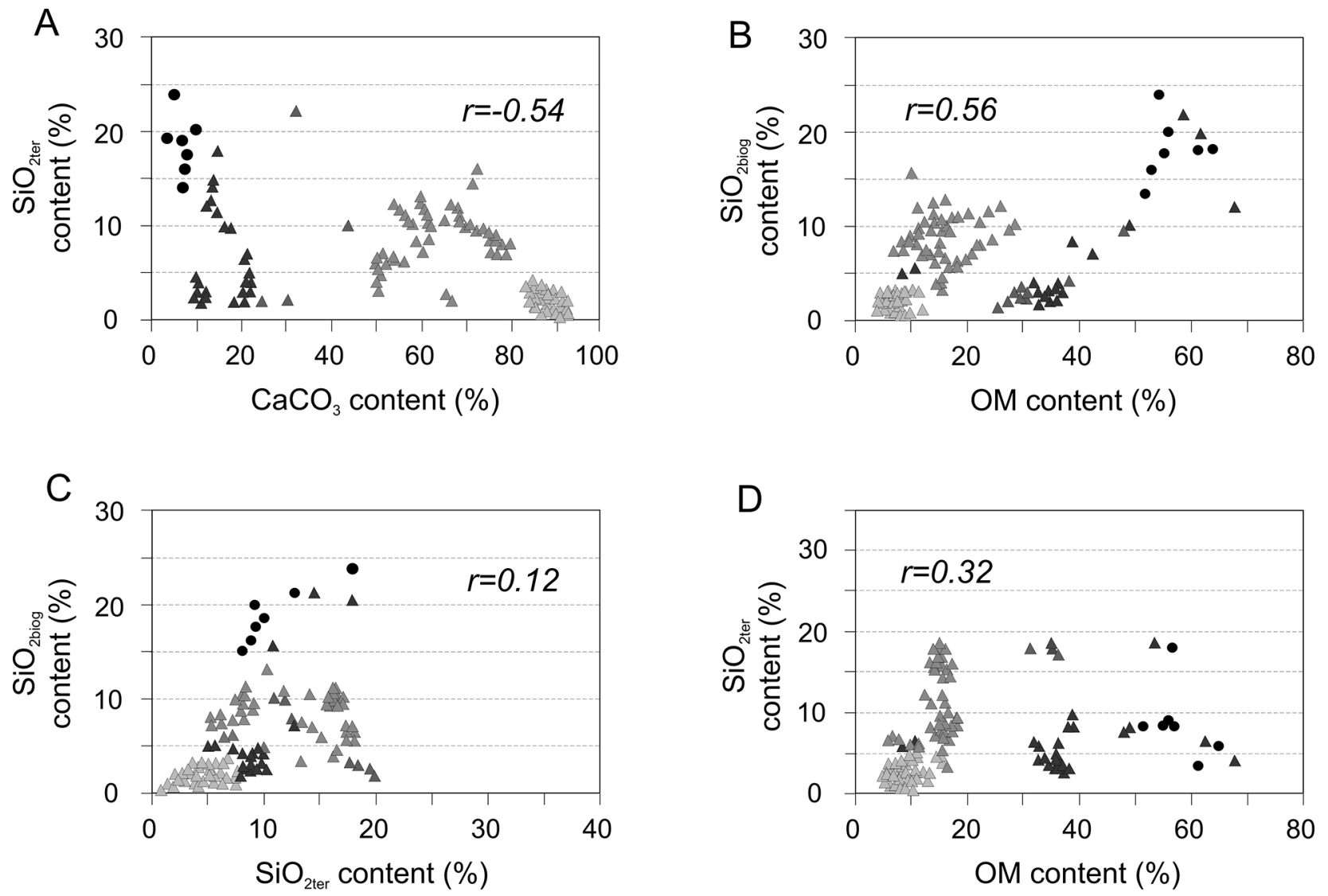

\section{$\triangle 1 \Delta 2 \Delta 3 \Delta 4 \quad \bullet$}

Fig. 5. Relationship between selected litho-geochemical elements: $\mathrm{SiO}_{2 \text { ter }}$ and $\mathrm{CaCO}_{3}(\mathrm{~A}), \mathrm{SiO}_{2 \text { biog }}$ and $\mathrm{OM}(\mathrm{B}), \mathrm{SiO}_{2 \mathrm{biog}}$ and $\mathrm{SiO}_{2 \text { ter }}(\mathrm{C})$ and $\mathrm{SiO}_{2 \text { ter }}$ and $\mathrm{OM}$ (D) within lake and peat deposits of the Wil-1 core; for lithology see Fig. 4.

ble 2). There is no sign of enrichment of these elements in the top part of the profile either, which was the case for other litho-geochemical components analysed (Fig. 3). The concentrations of trace elements in sediments of the Wil-1 core are clearly higher than the deposits in other reservoirs of biogenic accumulation in Poland (Bojakowska \& Lech, 2008). 
Daniel Okupny et al.

Table 2. Correlation matrix $(r)$ and coefficient of determination $\left(R^{2}\right)>0.5$ between contents of selected metals in deposits of the Wil-1 core.

\begin{tabular}{ccccccccccc}
\hline $\mathrm{r} / \mathrm{R}^{2}$ & $\mathrm{Na}$ & $\mathrm{K}$ & $\mathrm{Ca}$ & $\mathrm{Mg}$ & $\mathrm{Fe}$ & $\mathrm{Mn}$ & $\mathrm{Cu}$ & $\mathrm{Zn}$ & $\mathrm{Cr}$ & $\mathrm{Ni}$ \\
\hline $\mathrm{Na}$ & 1 & & & & & & & & & \\
$\mathrm{~K}$ & 0.41 & 1 & & & & & & 0.69 & 0.50 \\
$\mathrm{Ca}$ & 0.29 & -0.11 & 1 & & & & & & \\
$\mathrm{Mg}$ & 0.36 & -0.13 & 0.52 & 1 & & & & & \\
$\mathrm{Fe}$ & 0.17 & 0.69 & -0.31 & -0.36 & 1 & & & & \\
$\mathrm{Mn}$ & -0.12 & -0.39 & -0.17 & -0.24 & 0.07 & 1 & & & \\
$\mathrm{Cu}$ & 0.07 & 0.05 & -0.23 & -0.31 & 0.35 & 0.21 & 1 & & \\
$\mathrm{Zn}$ & 0.05 & 0.83 & -0.35 & -0.38 & 0.62 & -0.22 & 0.07 & 1 & & \\
$\mathrm{Cr}$ & -0.16 & -0.71 & 0.28 & 0.11 & -0.41 & 0.42 & 0.26 & -0.66 & 1 & \\
$\mathrm{Ni}$ & 0.19 & 0.09 & -0.19 & -0.03 & 0.29 & 0.09 & 0.09 & -0.01 & 0.13 & 1 \\
\hline
\end{tabular}

Wilkostowo Wil-1 core $(\mathrm{n}=55)$

\subsection{Geochemical stratification of the Wil-1 log}

The vertical variation in chemical composition of sediments depends on their lithological structure and the conditions of their sedimentation. As a result of a hierarchical cluster analysis, five developmental phases (including three natural and two anthropogenic) of the reservoir of biogenic accumulation at Wilkostowo were determined.

Phase 1 (W-I zone; $220-196 \mathrm{~cm}$ ) took place in the older Atlantic period (9141 cal. a BP); it had a natural character and included detritus-calcareous gyttja with a small interbedding of clay-calcareous gyttja. An increased content of such elements as: $\mathrm{Na}, \mathrm{K}$ or $\mathrm{Ni}$, confirms the natural and high mechanical denudation of the catchment area during deposition in the lake. The above-mentioned elements may be strongly absorbed by clay minerals, which cause the possibility of complex absorption being characterised by much higher contents of particular elements while forming the sedimentary cover than in an aqueous solution (Woszczyk \& Spychalski, 2007). In this period the increased content of $\mathrm{Zn}$, an element susceptible to intensive bioaccumulation by certain plant species, was quite common. It was most likely caused by widespread plant communities with significant or even dominant presence of Betula, which at the time was developing in the vicinity of the palaeolake (Rzepecki et al., 2015). Betula displays a bioaccumulative tendency towards Zn, which was noted by Fortescue (1980) and Reimann et al. (2007). Generally, in the older Atlantic Period Pinus sylvestris still played an important part in building forest communities. However, communities of Quercus, Alnus, Fraxinus excelsior and Corylus were gaining increasing foothold (Ralska-Jasiewiczowa et al., 1998; Nalepka, 2008).
The recorded variability of the content of macroand micro-elements attributed to the next - natural stage of the development of the reservoir (W-II zone; $196-100 \mathrm{~cm}$ ). It shows a gradual change in the nature of denudation in the environment of the lake - from mechanical to chemical (six-fold predominance of $\mathrm{Na}$ over $\mathrm{K}$ concentration and over 300 hundred-fold of Ca over $\mathrm{Mg}$ content). The rapid increase in $\mathrm{CaCO}_{3}$ content (up to nearly 80 per cent) results from the presence of calcium bicarbonate in lake waters and the biogenic decalcification of the lake waters caused by a high biomass of aquatic macrophytic nature. Good oxygenation of waters during sedimentation of these deposits at Wilkostowo is defined by a low value of Fe/ Mn (mean value does not exceed 30) and a low OM content (mean value does not exceed 15 per cent), which is caused by rapid decomposition of organic remains.

Sedimentation of calcareous gyttja was interrupted by an increased supply of OM and lithophilous elements (first anthropogenic zone: W-III; 100 $-80 \mathrm{~cm}$ ). A similar situation (i.e., a sharp decline in $\mathrm{CaCO}_{3}, \mathrm{SiO}_{2 \text { ter }}$ and $\mathrm{SiO}_{2 \text { biog }}$ at the expense of OM content) takes place at a depth of 88 to $84 \mathrm{~cm}$ (Fig. 3). $\mathrm{The} \mathrm{Na} / \mathrm{K}, \mathrm{Ca} / \mathrm{Mg}$ and $\mathrm{Fe} / \mathrm{Mn}$ ratios display considerable variability (Fig. 6). The chemical composition of these layers is a record of increased erosion processes in the catchment of the lake, an increase in water eutrophication, a change in the nature of the denudation from chemical to mechanical and the restriction of the leaching of soils in the catchment of the lake. An analysis of the chemical composition of the sediments, whose deposition occurred during the late Meso- and Neoholocene (4976 cal. a BP) shows that an explicit mark of man-made impact is preceded by an increase and then a decrease in the content of elements such as $\mathrm{Ca}$ and $\mathrm{Cu}$. This may be due to the inhibited recirculation caused by the 
increased intensity of the groundwater outflow and acidification of soils in the catchment of the lake. The high variability of depositional conditions can be seen as an abrupt change of the curve, which presents a threefold increase of the $[\hat{r}]$ marker. The high degree of decomposition $\left(\mathrm{H}_{9}-\mathrm{H}_{10}\right)$ of organic remains in the $\mathrm{W}$-III zone may be associated with sedimentary hiatus in the Atlantic period. It is possible that these changes were the results of a fire. Therefore, the processes of prehistoric human impact, recorded in the chemical composition of sediments that are classified as belonging to zone W-III, may probably be attributed to the TRB culture. The location of TRB settlements near an area of relatively "sandy soils" is confirmed in the middle Tąży- na River Valley (Domańska et at., 2013). Across the entire Tążyna River Valley, the TRB settlers were particularly interested in the mixed climax forest environments, and this was also the case for Wilkostowo. Mixed deciduous forests, composed of Quercus, Tilia, Ulmus, Fraxinus excelsior and Corylus in various combinations, were dominant in the Kuyavian landscape and the neighbouring areas during the Atlantic (Ralska-Jasiewiczowa et al., 1998; Nalepka, 2005, 2008; Karasiewicz et al., 2014). A core fragment from the nearby peatbog of Przybranówek, which can be identified as belonging to the Atlantic Period, shows low thickness of biogenic sediments, which indicates slow accumulation and suggests a possible hiatus in the processes of
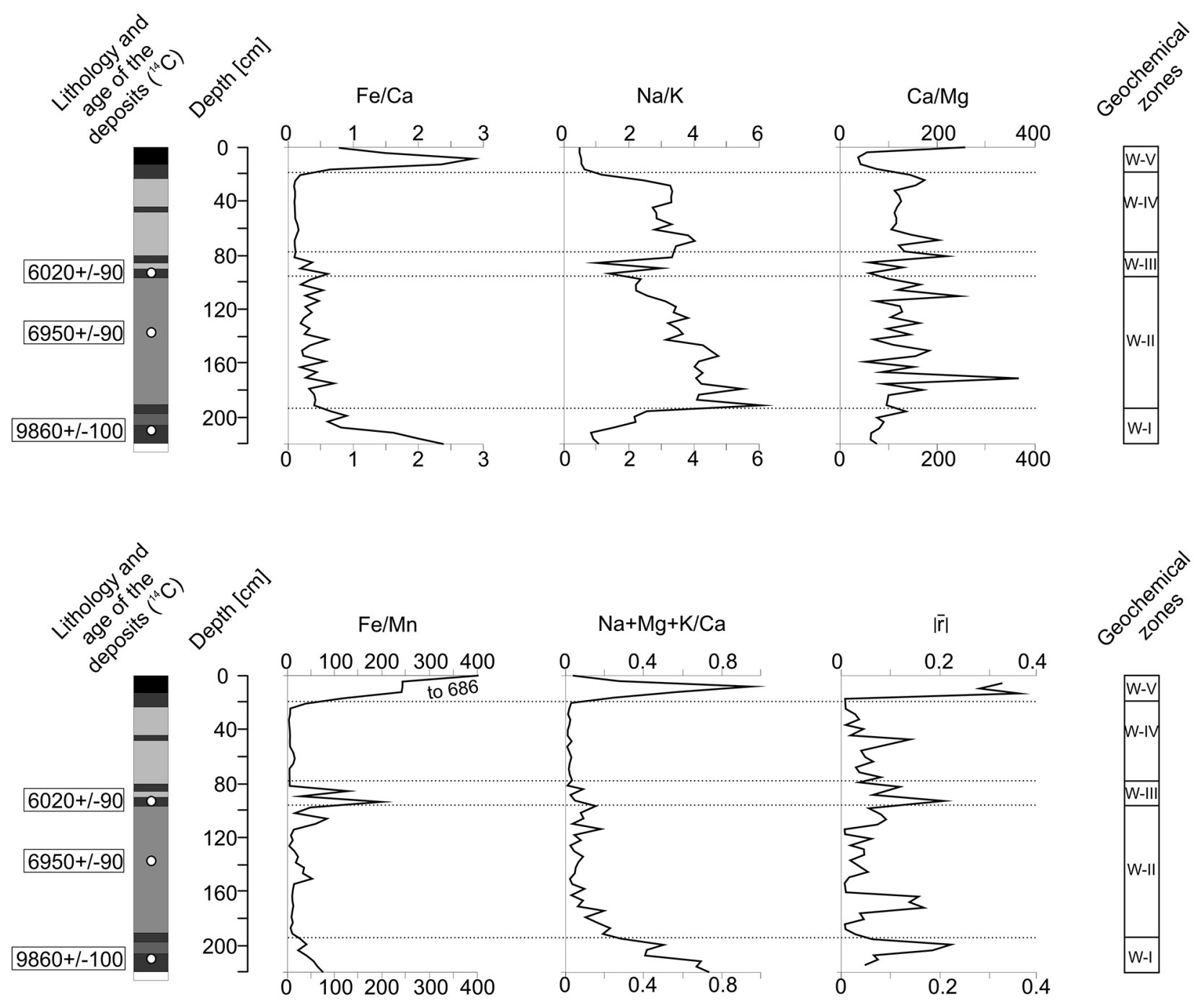

$1 \square 2 \square 3 \square 4 \square 5 \square 6$

Fig. 6. Vertical differences in selected geochemical parameters and geochemical zones within the deposits of the Wil-1 core; for lithology see Fig. 3. 
biogenic sedimentation. It was probably the reason for the lack of markers of anthropopression in the pollen samples (especially of cultivated plants) associated with Neolithic settlement groups. The sediments from the Przy-1 core contained only a minor presence of carbon dust, a low amount of Pteridium aquilinum spores, a single grain of Utrica pollen as well as a small amount of pollen classified as ruderalis (Rzepecki et al., 2015). In the charred level of palynological diagrams for the Osłonki site at the turn of the Meso- and Neoholocene pollen was also absent or degraded (Bogucki et al., 2012). Palaeobotanical research at the Gościąż site has allowed correlation of the settlement phase attributed to TRB population with rapid fluctuation of the AP curve (arboreal and shrub pollen) and the percentage maxima of the whole group of cultural indicator forms (Ralska-Jasiewiczowa \& Van Geel, 1998).

It is possible that an important factor influencing the chemical composition of the sediments in the two layers of detritus-calcareous gyttja described above, was increased lake water salinity - as a result of the increased productivity of saline water sources located in the vicinity of Inowrocław. The level of salinity of the lake water is an important factor for the circulation of $\mathrm{Fe}, \mathrm{Mn}, \mathrm{Al}, \mathrm{Mg}$ and $\mathrm{CaCO}_{3}$. In line with the views of Liss (1976), an increase in the salinity of the lake water during that period can be proved by the twofold increase in Fe and $\mathrm{Mg}$ in relation to the geochemical background. As that author thinks, the intense sedimentation of the above-elements, during higher salinity levels, was due to the process of coagulation of solid particles suspended in water under increased ionic strength conditions. However, both $\mathrm{Fe}$ and $\mathrm{Mg}$ - because of strong correlation with e.g., $\mathrm{SiO}_{2 \text { ter }}$ - are counted among the lithophilous elements and those could have been passively transported to the lake at Wilkostowo. On the other hand, Schettler et al. (2006) and Woszczyk (2016) underlined that $\mathrm{Mg}$ played an important role as inhibitor of $\mathrm{CaCO}_{3}$ precipitation in saline waters. This is confirmed by a decrease of $\mathrm{CaCO}_{3}$ content in the sediments obtained at Wilkostowo where, at the depths mentioned, the share of this component in the volume of the sample falls almost sixfold. The highest values of $\mathrm{Mg}$ in the whole section may have resulted from the economic exploitation of carnallite (hydrated potassium and magnesium chloride; $\mathrm{KMgCl}_{3} \times 6 \mathrm{H}_{2} \mathrm{O}$ ), which often accompanies deposits of halite (rock salt) in Kuyavian (Poborski et al., 1956). The Na content in this geochemical zone does not exceed $0.25 \mathrm{mg} /$ g.d.m., which is the maximum value characteristic of many sites of lacustrine sediments and peat in the Polish Lowland that are well documented in the specialised literature (Łacka et al., 1998; Apolinarska et al., 2012; Karasiewicz et al., 2014). The possibility of using local sources of salt (halite) by inhabitants is confirmed by the investigation of mineralogical pottery done by Pawlikowski (2015).

The next natural phase in basin development (W-IV zone; $80-24 \mathrm{~cm}$ ) includes the lacustrine chalk with a thickness of about $60 \mathrm{~cm}$ with small interbeddings of detritus-calcareous gyttja at a depth of $48-46 \mathrm{~cm}$. The high level of $\mathrm{Ca}$ and $\mathrm{Na}$ in relation to $\mathrm{Mg}$ and $\mathrm{K}$ in the lacustrine chalk, respectively, are indicative of persistent lake alimentation by groundwater enriched with products of the chemical denudation of glacial and glaciofluvial deposits. This phase of lake development probably corresponds to the humid period $5150 \pm 400 \mathrm{cal}$. a BP, which was identified in lakes of northern Poland (Michczyńska et al., 2013). At the turn of the Atlantic and Subboreal periods, mesophilous deciduous mixed forests continued to be the predominant vegetation type but reduction of the forested areas is recorded in the sediments of Przybranówek mire (Rzepecki et al., 2015). An analysis of the cores from the Holocene carbonate sediments deposited in lakes and peatbogs of northern Poland allows to distinguish the key differences in the period of their deposition and their chemical composition (Eacka et al., 1998; Rutkowski et al., 2007; Apolinarska et al., 2012; Mazurek et al., 2014). Those may have been determined by the sites being situated either in the highland or a valley as well as local geological and morphological conditions that determine the type of water supply. The lowest values of the ratio Fe/Mn (average - about 7) indicate that lacustrine chalk accumulated under more oxidising conditions, probably linked to an ascending water supply to the lake. The three periods of a small increase in erosion rate in the catchment of the lake recorded in this layer coincide with intervals of a slight rise in eutrophication of the lake waters and a decrease in the intensity of $\mathrm{CaCO}_{3}$ precipitation. The largest increase of the correlation between different measurement results $[\hat{r}]$ is the record of a greater variability of the conditions of sedimentation in detritus-calcareous gyttja (Fig. 6). Most likely, these periods can be attributed to human activity during the Bronze and Iron ages.

The sedimentation of detritus-calcareous gyttja and the highly decomposed $\left(\mathrm{H}_{8}\right.$ by von Post scale) herbaceous peat (second anthropogenic zone: $\mathrm{W}-\mathrm{V}$; $24-0 \mathrm{~cm}$ ) are indicative of the process of overgrowth of the lake. The maximum content of $\mathrm{Zn}$ and $\mathrm{Fe}$ in the entire vertical section proves the existence of strongly reducing conditions in the reservoir. An increased concentration of elements such 
as $\mathrm{K}, \mathrm{Na}$ or $\mathrm{Pb}$ results from processes of mechanical denudation within the catchment area of the sedimentary basin described. These elements are amongst the most important inorganic constituents in peat deposits and their increased content may be the result of delivery from allochthonous mineral matter, independently of the natural development of the mire (Rydelek, 2013). The highest concentrations of $\mathrm{Pb}$ were discovered at depths at which the content of mineral matter falls, and therefore a supply of this metal into the study site area is associated with atmospheric migration of particles. The average concentration of trace elements ( $\mathrm{Zn}$ and $\mathrm{Pb}$ ) in the upper part of the Wil-1 core is similar to the Holocene overbank deposits in the Tążyna River Valley (Szmańda, 2008). In comparison with the soils of the Kuyavian Lakeland (e.g., Cieśla et al., 1994; Dąbkowska-Naskręt et al., 2006) the peat deposits studied here contain less $\mathrm{Cr}, \mathrm{Cu}, \mathrm{Ni}$ and $\mathrm{Pb}$, and contain only more $\mathrm{Zn}$.

\subsection{Causes of geochemical variation of sediments at Wilkostowo}

Using Kaiser's criterion, those factors that have a value greater than 1 (principal component) were distinguished (Fig. 7). The first four are significant (PC1, PC2, PC3 and PC4), which explains a total of 82.2 per cent of the variance.

The first component (PC1) is strongly positively correlated $(\mathrm{r}>0.6)$ with $\mathrm{OM}, \mathrm{SiO}_{2 \text { ter }} \mathrm{K}$, Fe and $\mathrm{Zn}$ (Fig. 8A). The co-existence of these elements can be regarded as a universal phenomenon that results from the absorption of metals by clay minerals, organic matter and hydrated iron oxides, the co-existence of elements in rocks of the earth's crust, precip-

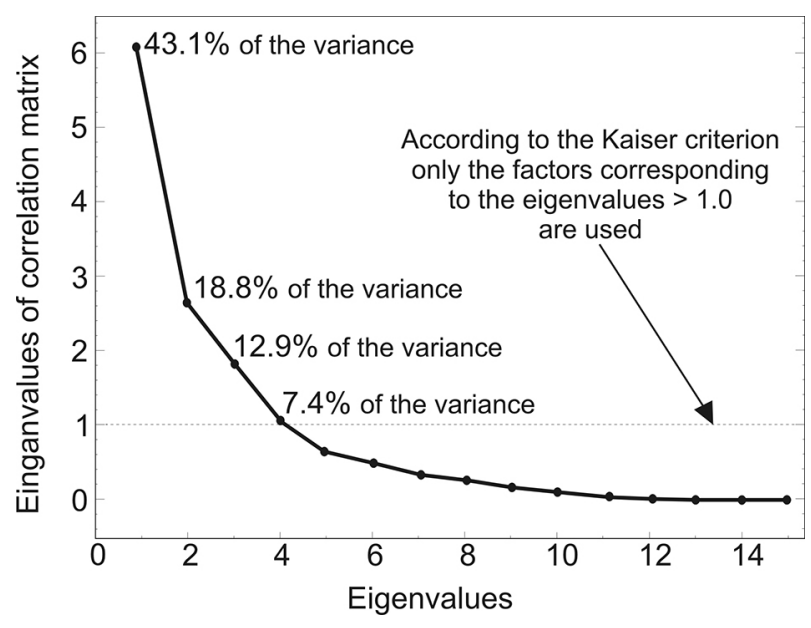

Fig. 7. Eigenvalues of correlation matrix for a set of results of chemical analysis for deposits of the Wil-1 core. itation of sulphide metal with limited oxygenation and weak decomposition of organic matter (Woszczyk \& Spychalski, 2007). The curves of $\mathrm{SiO}_{2 \text { biog }}$ and OM content in the Wil-1 core sediments may reflect real changes in intensity of biological processes in the lake reservoir at Wilkostowo, which are hinted at by the positive correlation between $\mathrm{SiO}_{2 \text { ter }}$ and $\mathrm{SiO}_{2 \text { biog }}$ and the OM (Fig. 5B, D). The clay minerals and $\mathrm{Fe}$ oxides played a major role in the process of retention of solids dissolved in the lake's water in the reservoir at Wilkostowo. The $\mathrm{K}$ content, which is part of the aluminosilicate, is a measure of the relative concentration of clay minerals in biogenic deposits (Last, 2001; Rydelek, 2013). Moreover, the PC1 component negatively correlates with the $\mathrm{pH}$ and $\mathrm{CaCO}_{3}$ content (Fig. 8A). The high value of the average content of $\mathrm{CaCO}_{3}$ (56.9 per cent) is explained by low biological productivity of lakes with highly alkaline waters. According to this interpretation, deposits with a reduced $\mathrm{CaCO}_{3}$ content record a decreased alkalinity of the lake water and a weaker binding of phosphorous in the sediments (Dittrich \& Koschel, 2002). Such conditions favour the development of diatom populations and SiO2biog deposition (Woszczyk, 2011). The enrichment of metals such as $\mathrm{K}, \mathrm{Fe}$ and $\mathrm{Ni}$ (geochemical zone: W-III) may indicate an increased intensity of human activity in the catchment of the lake (i.e., the use of saline waters for economic purposes or aeolian processes during the Neolithic). At this level the content of PC1 was highest (Fig. 8B). The remaining part of the log contains levels of PC1 values of high vertical variability with marked spikes in places where the OM content (detritus-calcareous gyttja and highly decomposed herbaceous peat) is higher and drops in places where calcareous gyttja and lacustrine chalk are present.

The second component (PC2) is positively correlated with $\mathrm{SiO}_{2 \text { ter, }} \mathrm{Mn}, \mathrm{Cu}, \mathrm{Cr}$ and Ni contents (Fig. $8 \mathrm{~A})$. The highest values of PC2, indicative of a rich presence of trace elements and $\mathrm{SiO}_{2 \text { ter }}$, were identified as belonging to the initial phase of the development of the reservoir (Fig. 8B). The remainder of the log shows this variable as a limited vertical variability, with the exception of the highly decomposed herbaceous peat. Generally, the sections rich in $\mathrm{SiO}_{2 \text { ter }}$ and $\mathrm{Mn}$, may indicate some episodic activation of fluvial processes, a supply of mineral matter by aeolian processes - spurred by man - in the areas cleared of vegetation that are parts of the sandur level. Because of low slope inclination in the area, the influence of slope processes on the delivery of the elements to the Wilkostowo reservoir appears less likely. The Holocene aeolian processes, which were in part synchronous with TRB cultural 

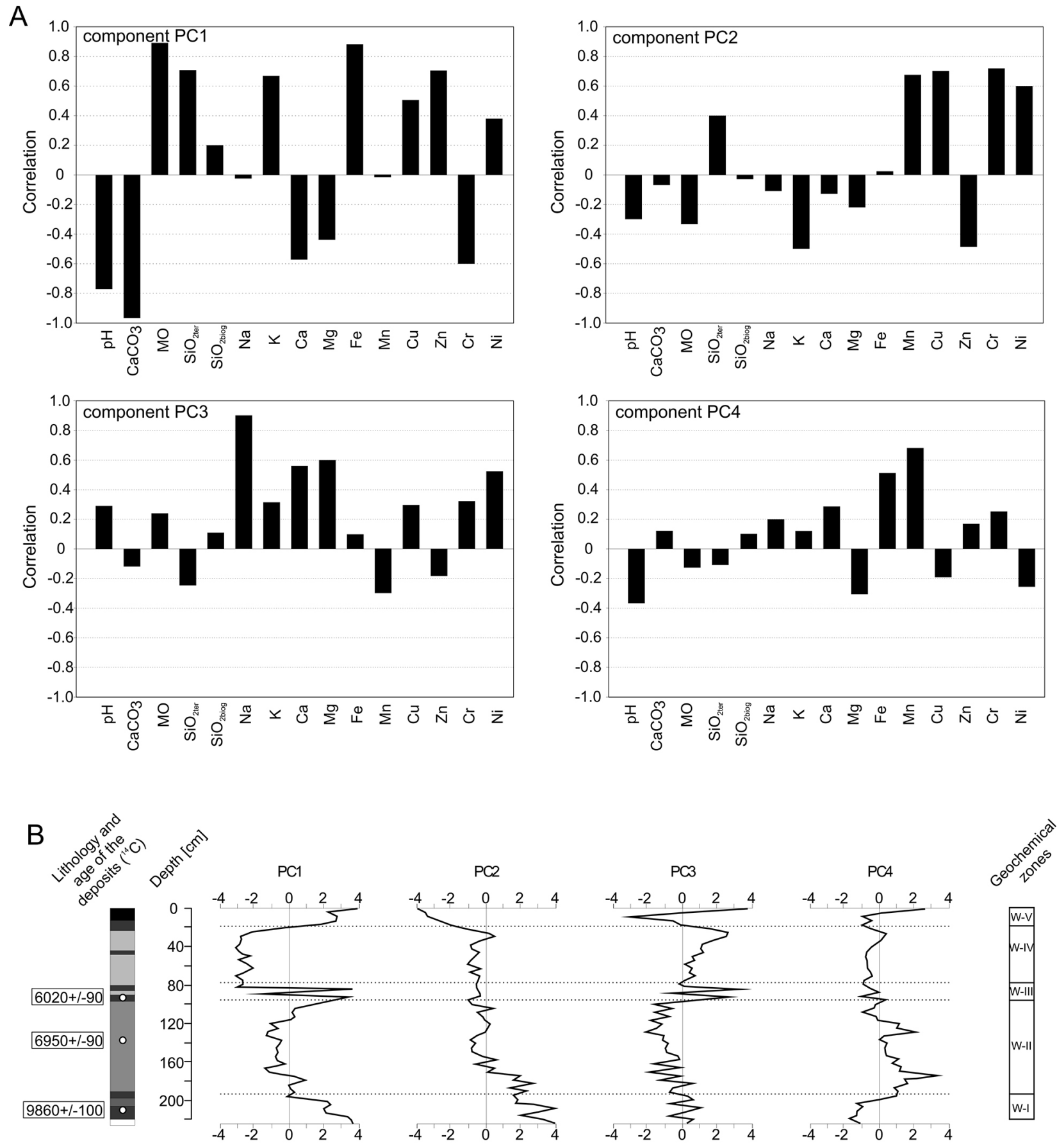

Fig. 8. Correlation of geochemical variables with four first principal components for a set of results of chemical analysis (A) and plots of principal components PC1-PC4 (B) from deposits of the Wil-1 core; for lithology see Fig. 3.

development, were reconstructed on the grounds of several examples from the neighbouring Torun Basin (Jankowski, 2002). However, other possible processes of geochemical cycle of $\mathrm{Mn}$ in the lake include: precipitation of manganese carbonate in terms of abundant organic matter, no free $\mathrm{O}_{2}$ and excess $\mathrm{CO}_{2}$ in a deposit-forming environment, and impact of diagenetic migration to vertical and spatial distribution of Mn compounds (Davison et al., 1982; Granina et al., 2004).

Trace elements such as $\mathrm{Cu}, \mathrm{Cr}$ and Ni migrate passively. They are absorbed by mineral matter and exhibit sulphophile ability (Landner \& Reuther, 2004). No statistically significant correlations of 
$\mathrm{Cu}$ with the other components could be a result of a very different stability organometallic $\mathrm{Cu}$ compounds. This stability depends on conditions within the deposits, the degree of decomposition and humification of $\mathrm{OM}$ and $\mathrm{pH}$ of the deposit-forming environment (Woszczyk \& Spychalski, 2007). Distribution of trace elements in lake sediments is strongly dependent on the type of geological formation on which the lake is developed and the sedimentation zone of the lake (Poepperl et al., 2001).

The third component (PC3) explains mainly the variation of $\mathrm{Na}, \mathrm{Mg}$ and $\mathrm{Ca}$ (Fig. 8A). The PC3 component exhibits significant cross-sample fluctuations, especially at a depth of 2.2 to $0.8 \mathrm{~m}$ (Fig. 8B). The maximum values of this parameter correspond with the highest PC1 values and can be found in sediments containing more OM (detritus-calcareous gyttja and highly decomposed herbaceous peat). The highest content of $\mathrm{Na}, \mathrm{Mg}$ and $\mathrm{Ca}$ was documented in carbonate sediments. These elements are the main components of lacustrine chalk or calcareous gyttja and could have been supplied to the biogenic reservoirs as a result of chemical denudation processes (Stumm, 2003). The increasing importance of leaching processes of $\mathrm{Na}, \mathrm{Mg}$ and $\mathrm{Ca}$ from the catchment can result from changes in vegetation and increased water permeability in soils.

The fourth component (PC4) is strongly positively correlated $(r>0.5)$ with those of Fe and $\mathrm{Mn}$ (Fig. 8A). In the bottom part, the PC4 values show high vertical variability (Fig. $8 \mathrm{~B}$ ). The maxima correspond with low PC1 level and can be associated with sediments with the highest concentration of $\mathrm{Mn}$. On the other hand, in the lacustrine chalk sediment the PC4 component displays low cross-sample fluctuation, similar to PC1 and PC2. The concentration of $\mathrm{Fe}$ in the studied detritus-calcareous gyttja and peat is much higher than in the other lake deposits, showing the deterioration of redox conditions. In contrast, ferrous oxide was an important part of the process of binding with substances dissolved in water as well as in the migration of numerous elements. $\mathrm{K}, \mathrm{Na}$ and $\mathrm{Cu}$ were quickly captured by surfactants and reached the reservoir in suspension. Also, Fe was grouped in factor explaining the chemical composition in the biogenic sediments of Lake Sarbsko (Woszczyk \& Spychalski, 2007). The Fe and Mn concentrations in bottom deposits depend on the average contents of these elements in the rocks forming the catchment, the intensity of mechanical denudation, the oxidation-reduction conditions in the soils of the catchment, the presence or absence of sulfur, precipitation of Mn and Fe carbonates in terms of the abundance of $\mathrm{OM}$ and the impact of diagenesis migration (Emerson, 1978; Davison et al., 1982; Dean, 1999).

\section{Conclusions}

A thick (up to $220 \mathrm{~cm}$ ) layer of biogenic sediments was studied in the mid-section catchment areas of the River Tążyna, as a source of knowledge of the environment since the Mesoholocene. Sediments of the Wil-1 core are characterised by a high stratigraphic geochemical variability expressed both as the content of the main litho-geochemical components as well as the content of elements. The geochemical features of the biogenic deposits are typical of calcareous gyttja and lacustrine chalk. The limnic sediments were deposited as an effect of intensive chemical denudation processes. The geochemical properties of the peat were formed by the deterioration of redox conditions, intensified erosion of the catchment, metal pollution and acidification.

The results from our geochemical survey have made it possible to reconstruct the main stages in the evolution of the lake basin at Wilkostowo. The main factors influencing the chemical composition of the sediments studied include: the geological structure and lithology in the catchment of the reservoir, the water supply type and the water balance of the basin as well as changes in variation pattern of intensity and type of denudation in the catchment area. The curves of the factor values in the Wil-1 log display a connection between the change in the content of a number of metals $(\mathrm{Ca}, \mathrm{Mg}, \mathrm{Na}$ and $\mathrm{Fe}$ ) and the lithological alteration. The bottom part of the log shows a high vertical variability in levels of all factors, while the phases of the most intensive growth or decrease can be seen in levels of a Meso- and Neoholocene date.

The effects of the prehistoric anthropogenic activities in the catchment area of the mid-section of the River Tążyna are detectable in changes in sedimentation of biogenic calcareous gyttja into detritus-calcareous gyttja.

The increased human activity of the middle Tążyna River Valley in the Neolithic Age manifested itself by an increase in content of lithophilous elements $(\mathrm{Na}, \mathrm{K}, \mathrm{Mg}$ and $\mathrm{Ni}$ ) in the sediments, an increase in the value of the erosion rate in the catchment of the lake, an increased eutrophication of the lake, a change in the nature of the processes of denudation, a decrease in the intensity of leaching $\mathrm{CaCO}_{3}$ from the catchment area and a reduction in the $\mathrm{pH}$ of the soil cover. The greater admixture of $\mathrm{SiO}_{2 \text { ter }}$ in the limnic deposits can be attributed to aeolian processes. 
The top position occupied by $\mathrm{Mg}$ and Fe amongst migrating elements, together with a lowered $\mathrm{CaCO}_{3}$ content in sediments deposited during the Neolithic, suggests the use of saline waters for economic purposes.

\section{References}

Aaby, B., 1986. Palaeoecological studies of mires. [In:] B.E. Berglund (Ed.): Handbook of Holocene Palaeoecology and Palaeohydrology. John Wiley \& Sons, Chichester, 145-165.

Andrzejewski, L., 1995. Genesis of the fluvial system of the lower Vistula river based on the selected side valleys. Geographical Studies, Special Issue 6, 139-156.

Andrzejewski, L. \& Weckwerth, P., 2010. Dunes of the Torun Basin against palaeogeographical conditions of the Late Glacial and Holocene. Ecological Questions 12, 9-15.

Apolinarska, K., Woszczyk, M. \& Obremska, M., 2012. Late Weichselian and Holocene palaeoenvironmental changes in northern Poland based on the Lake Skrzynka record. Boreas 41, 292-307.

Birch, L., Hanselmann, K.W. \& Bachofen, R., 1996. Heavy metal conservation in Lake Cadagno sediments: historical records of anthropogenic emissions in a meromitic alpine lake. Water Research 30, 3, 679-687.

Błaszkiewicz, M., 2007. Geneza i ewolucja mis jeziornych na młodoglacjalnym obszarze Polski - wybrane problemy [The origin and evolution of recesses of lakes upper Vistulian glaciated area on Polish territory - selected problems]. Studia Limnologica et Telmatologica 1, 1, 5-16.

Bogucki, P., Nalepka, D., Grygiel, R. \& Nowaczyk, B., 2012. Multiproxy environmental archaeology of Neolithic settlements at Osłonki, Poland, 5500-4000 BC. Environmental Archaeology 17, 1, 45-65.

Bojakowska, I. \& Lech, D., 2008. Zróżnicowanie zawartości pierwiastków śladowych w torfach występujących na obszarze Polski [Variance of trace elements contents in peats occurred in Poland area]. Zeszyty Naukowe Politechniki Ślaskiej, Seria Górnictwo 285, 31-41.

Bronk Ramsey, C., 2009. Bayesian analysis of radiocarbon dates. Radiocarbon 51, 337-360.

Chambers, F.M. \& Charman, D.J., 2004. Holocene environmental change: contributions from the peatland archive. The Holocene 14, 1-6.

Cieśla, W., Dąbkowska-Naskręt, H., Długosz, J. \& Zalewski, W., 1994. Evaluation of microelements contents in arable soils of eastern Wielkopolska Lowland. Soil Science Annual 44, 79-84.

Cohen, A.S., 2003. Paleolimnology: The History and Evolution of Lake Systems. Oxford University Press, 528 pp.

Czerwiński, Z., 1996. Zasolenie wód i gleb na terenie Kujaw [Salinity of waters and soils in the Kujawy region]. Roczniki Gleboznawcze 47, 3-4, 131-143.

Davison, W., Woof, C. \& Rigg, E., 1982. The dynamic of iron and manganese in seasonal anoxic lake; direct measurements of fluxes using sediments traps. Limnology and Oceanography 27, 6, 987-1003.
Dąbkowska-Naskręt, H., Długosz, J., Jaworska, H., Kobierski, M., Malczyk, P., Bartkowiak, A. \& Różański, S., 2006. Variability of zinc content in surface horizons of soils from the Eastern Part of the Wielkopolska Lake District. Polish Journal of Environmental Studies, 15(2A): 52-55.

Dean, W.E., 1999. The carbon cycle and biogeochemical dynamics in lake sediments. Journal of Paleolimnology 21, 375-393.

Dittrich, M. \& Koschel, R., 2002. Interactions between calcite precipitation (natural and artificial) and phosphorus cycle in the hardwater lake. Hydrobiologia 468, 1, 49-57.

Domańska, L., Forysiak, J., Rzepecki, S. \& Twardy, J., 2013. The TRB culture settlement in the Middle Tążyna Valley: a case study. [In:] S. Kadrow \& P. Włodarczak (Eds): Environment and subsistence - forty years after Janusz Kruk's "Settlement studies...". Studien zur Archäologie in Ostmitteleuropa 11, 105-116.

Drzymulska, D., 2016. Peat decomposition - shaping factors, significance in environmental studies and methods of determination; a literature review. Geologos 22, 61-69.

Emerson, S., 1978. Early diagenesis in anaerobic lake sediments - II. Thermodynamic and kinetic factors controlling the formation of iron phosphate. Geochimica Cosmochimica Acta 42, 1307-1316.

Fiałkiewicz-Kozieł, B., Smieja-Król, B. \& Palowski, B., 2011. Heavy metal accumulation in two peat bogs from Southern Poland. Studia Quaternaria 28, 17-24.

Fortescue, J.A.C., 1980. Environmental geochemistry. A holistic approach. Springer-Verlag, New York, 347 pp.

Gorham, E. \& Swaine, D.J., 1965. The influence of oxiding and reducing conditions upon the distribution of some elements in lake sediments. Limnology and Oceanography 10, 2, 268-279.

Goździk, J., 1995. A permafrost evolution and its impact on some depositional conditions between 20 and 10 ka in Poland. Biuletyn Peryglacjalny 34, 53-72.

Granina, L., Müller, B. \& Wehrli, B., 2004. Origin and dynamics of Fe and Mn sedimentary layers in Lake Baikal. Chemical Geology 205, 55-72.

Hammer, O., Harper, D.A.T., Ryan, P.D., 2001. PAST: Paleontological Statistics software package for education and data analysis. Palaeontologia Electronica 4, 1-9.

Heiri, O., Lotter, A.F., \& Lemcke, G., 2001. Loss on ignition as a method for estimating organic and carbonate content in sediments, reproducibility and comparability of results. Journal of Paleolimnology 25, 101-110.

Hulisz, P., 2007. Propozycja systematyki gleb zasolonych występujących $\mathrm{w}$ Polsce [Proposal of systematic of Polish salt-affected soils]. Roczniki Gleboznawcze 58, 121-129.

Jankowski, M., 2002. Buried soils in the dunes of the Toruń Basin. [In:] B. Manikowska, K. Konecka-Betley \& R. Bednarek (Eds): Paleopedology problems in Poland. Łódzkie Towarzystwo Naukowe, Łódź, 233-252.

Jones, B.F. \& Bowser, C.J., 1978. The mineralogy and related chemistry of lake sediments. [In:] A. Lerman (Ed.): Lakes: Chemistry, Geology, Physics. Springer-Verlag, Berlin, 179-236.

Kabata-Pendias, A., 2011. Trace elements in soils and Plants. Fourth edition. CRC Press, Boca Raton, 505 pp. 
Kalis, A.J., Merkt, J. \& Wunderlic, J., 2003. Environmental changes during the Holocene climatic optimum in central Europe - human impact and natural causes. Quaternary Science Review 22, 33-79.

Karasiewicz, M.T., Hulisz, P., Noryśkiewicz, A.M., Krześlak, I. \& Świtoniak, M., 2014. The record of hydroclimatic changes in the sediments of kettle-hole in a Young glacial landscape (north-central Poland). Quaternary International 328-329, 264-276.

Krygowski, B., 1961. Physical geography of the Great Poland Lowland. P. I. Geomorphology. Poznańskie Towarzystwo Przyjaciół Nauki, Poznań, 1-203.

Landner, L. \& Reuther, R., 2004. Metals in Society and in the Environment. A Critical Review of Current Knowledge on Fluxes, Speciation, Bioavailability and Risk for Adverse Effects of Cooper, Chromium, Nickel and Zinc. Kluwer Academic Publishers, 407 pp.

Last, W., 2001. Mineralogical analysis of lake sediments. [In:] W.M. Last \& J.P. Smol (Eds): Tracking environmental change using lake sediments. Vol. 2. Physical and geochemical methods. Kluwer Academic Publishers, 143-187.

Legendre, P. \& Birks, H.J.B., 2012. From classical to canonical ordination. [In:] H.J.B. Birks, A.F. Lotter, S. Juggins \& J.P. Smol (Eds): Tracking Environmental Change using Lake Sediments. Vol. 5. Data handing and numerical techniques. Springer, Dordrecht, 201-248.

Liss, P.S., 1976. Conservative and non-conservative behaviour of dissolved constituents during estuarine mixing. [In:] J.D. Burton \& P.S. Liss (Eds): Estuarine chemistry. Academic Press, London, 93-130.

Łącka, B., Starnawska, E., Kuźniarski, M. \& Chróst, L., 1998. Mineralogy and geochemistry of the Lake Gościąż Holocene sediments. [In:] M. Ralska-Jasiewiczowa, T. Goslar, T. Madeyska \& L. Starkel (Eds): Lake Gościąz, Central Poland. A monography study. Part 1. W. Szafer Institute of Botany, Polish Academy of Sciences, 196-202.

Mackereth, F.J.H., 1965. Chemical investigation of lake sediments and their interpretation. Proceedings of the Royal Society of London, Series B, Biological Sciences 161, 984, 295-309.

Mangiamelli, P., Chen, S.K. \& West, D., 1996. A comparison of SOM neural network and hierarchical clustering methods. European Journal of Operational Research 93, 402-417.

Markowski, S., 1980. Struktura i właściwości podtorfowych osadów jeziornych rozprzestrzenionych na Pomorzu Zachodnim jako podstawa ich rozpoznawania i klasyfikacji [Structure and properties of lacustrine depostis dispersed in the Western Pomerania as a basis for their recognition and classification]. Kreda jeziorna i gytie. Vol. 2. Poznańskie Towarzystwo Przyjaciół Nauk o Ziemi, Gorzów-Zielona Góra, 44-55.

Marks, L., 2005. Pleistocene glacial limits in the territory of Poland. Przeglad Geologiczny 53, 988-993.

Martínez Cortizas, A., López-Merino, L., Bindler, R., Mighall, T. \& Kylander, M.E., 2016. Early atmospheric metal pollution provides evidence for Chalcolithic/ Bronze Age mining and metallurgy in Southwestern Europe. Science of the Total Environment 545/546, 398-406.
Mazurek, M., Dobrowolski, R. \& Osadowski, Z., 2014. Geochemistry of deposits from spring-fed fens in West Pomerania (Poland) and its significance for palaeoenvironmental reconstruction. Géomorphologie: relief, processus, envirionment 4, 323-342.

Michczyńska, D., Starkel, L., Nalepka, D. \& Pazdur, A., 2013. Hydrological changes after the last ice retreat in Northern Poland using radiocarbon dating. Radiocarbon $55,2-3,1712-1723$.

Minyuk, P.S., Borkhodoev, V.Y. \& Wennrich, V., 2014. Inorganic geochemistry data from Lake El'gygytgyn sediments: marine isotope stages 6-11. Climate of the Past 10, 467-485.

Nalepka, D., 2005. Late Glacial and Holocene Paleoecological Conditions and changes of vegetation cover under early farming activity in the South Kujawy Region (Central Poland). Acta Palaeobotanica, Supplement 6, 3-90.

Nalepka, D., 2008. Late Glacial and Holocene history of vegetation at Osłonki (Kujawy, Central Poland). Folia Quaternaria 78, 33-44.

Niewiarowski, W., Pasierbski, A. \& Tomczak, A., 1976. Mapa geologiczna Polski w skali 1:200 000, arkusz Toruń [Geological Map of Poland, 1: 200 000, sheet Toruń]. Wydawnictwa Geologiczne, Warszawa.

Nowaczyk, B., 2008. Changes in natural environment in the vicinity of Osłonki (Kujawy, Central Poland) in the light of geological and geomorphological investigations. Folia Quaternaria 78, 7-32.

Pawlikowski, M., 2015. Results of mineralogical and technological study of pottery and daub. [In:] S. Rzepecki (Ed.): Wilkostowo 23/24: a neolithic settlement in Kuyavia, Poland c. 3500 BC. Studien zur Archäologie in Ostmitteleuropa 15, 405-422.

Pawłowski, D., Milecka, K., Kittel, P., Woszczyk, M. \& Spychalski, W., 2015. Palaeocological record of natural changes and human impact in small river valley in Central Poland. Quaternary International 370, 12-28.

Poborski, J., Prochazka, K. \& Wala, A., 1956. Sole potasowo-magnezowe $\mathrm{w}$ złożach Inowrocławia i Wapna [Potassium-magnesium salts in Inowrocław and Wapno]. Acta Geologica Polonica 6, 4, 337-370.

Poepperl, R., Kluge, W., Schernewski, G., Garbe-Shonberg, C.D. \& Nellen, W., 2001. Spatial and Temporal Variability of Limnological Processes. [In:] J.D. Tenhunen, R. Lenz \& R. Hantschel (Eds): Ecosystem Approaches to Landscape Management in Central Europe. Ecological Studies 147, 117-162.

Ralska-Jasiewiczowa, M., van Geel, B. \& Demske, D., 1998. Holocene regional vegetation history recorded in the Lake Gościąż sediments [In:] M. Ralska-Jasiewiczowa, T. Goslar, T. Madeyska \& L. Starkel (Eds): Lake Gościąz, Central Poland. A monography study. P. 1. W. Szafer Institute of Botany, Polish Academy of Sciences, 202-219.

Ralska-Jasiewiczowa, M. \& van Geel, B., 1998. Human impact on the vegetation of the Lake Gościąż surroundings in Prehistoric and Early-Historic Times. [In:] M. Ralska-Jasiewiczowa, T. Goslar, T. Madeyska \& L. Starkel (Eds): Lake Gościąz, Central Poland. A mon- 
ography study. P. 1. W. Szafer Institute of Botany, Polish Academy of Sciences, 267-294.

Reimann, C., Arnoldussen, A., Boyd, R., Finne, T.E., Koller, F., Nordgulen, Ø. \& Englmaier, P., 2007. Element contents in leaves of four plant species (birch, mountain ash, fern and spruce) along antropogenic and geogenic concentration gradients. Science of Total Environment 377: 416-433.

Reimer, P.J., Bard, E., Bayliss, A., Beck, J.W., Blackwell, P.G., Bronk Ramsey, C., Buck, C.E., Cheng, H., Edwards, R.L., Friedrich, M., Groots, P.M., Guilderson, T.P., Haflidason, H., Hajdas, I., Hatte, C., Heaton, T.J., Hoffmann, D.L., Hogg, A.G., Hughen, K.A., Kaiser, K.F., Kromer, B., Manning, S.W., Niu, M., Reimer, R.W., Richards, D.A., Scott, E.M., Southon, J.R., Turney, C.S.M. \& van der Plicht, J., 2013. IntCal13 and Marine13 radiocarbon age calibration curves, $0-50,000$ years cal BP. Radiocarbon 55, 4, 1869-1887.

Rutkowski, J., Król, K. \& Szczepańska, J., 2007. Lithology of the profundal sediments in Słupiańska Bay (Wigry Lake, NE Poland) - introduction to interdisciplinary study. Geochronometria 27, 47-52.

Rösch, M. \& Lechterbeck, J., 2016. Seven Millennia of human impacts as reflected in a high resolution pollen profile from the profundal sediments of Litzelsee, Lake Constance region, Germany. Vegetation History and Archeobotany (in press) (http://dx.doi. org/10.1007/s00334.015.0552.9).

Rydelek, P., 2013. Origin and composition of mineral constituents of fen peats from eastern Poland. Journal of Plant Nutrition 36, 911-98.

Rzepecki, S. (Ed.), 2015. Wilkostowo 23/24: a neolithic settlement in Kuyavia, Poland c. 3500 BC. Studien zur Archäologie in Ostmitteleuropa 15, 487 pp.

Rzepecki, S., Obremska, M., Twardy, J., Forysiak, J. \& Okupny, D., 2015. Stanowisko Przybranówek. Zapis neolitycznej antropopresji w świetle analiz środowiskowych, materiałów archeologicznych i palinologicznych badań rdzenia z bagna „Katarzyna” [Przybranówek site. The record of Neolithic anthropogenic according to the analysis of environment al, archaeological material and palynological studies of the core the peatland „Katarzyna”]. [In:] D. Dzieduszyńska \& M. Roman (Eds): Dynamika zmian roślinności Niżu Polskiego w dobie późoglacjalnych zmian klimatu i narastania antropopresji w holocenie [Dynamics of changes in vegetation Polish Lowland in an late glacial period of climate change and human pressure rise in the Holocene]. Łódź, 75-79.

Schettler, G., Romer, R.L., O'Connell, M. \& Molloy, K., 2006. Holocene climatic variations and postglacial sea-level rise geochemically recorded in the sediments of the brakish karst lake An Loch Mór, western Ireland. Boreas 35, 674-693.

Schnurrenberger, D., Russell, J. \& Kelts, K., 2003. Classification of lacustrine sediments based on sedimentary components. Journal of Paleolimnology 29, 141-154.

Stumm, W., 2003. Chemical processes regulating the composition of lake waters. [In:] P.E. O' Sullivan \& C.S. Revnolds (Eds): The Lakes Handbook. Limnology and Limnetic Ecology. Blackwell, 79-106.
Stupnicka, E., 1989. Geologia regionalna Polski [Polish regional geology]. Wydawnictwa Geologiczne, Warszawa, 286 pp.

Szmańda, J., 2008. Interpretacja intensywności zdarzeń powodziowych w aluwiach wałów przykorytowych Drwęcy i Tążyny na podstawie zapisu sedymentologicznego i badań skażenia pierwiastkami śladowymi [Interpretation of the intensity of flood events in overbank deposits of the troughbank dam in Drwęca and Tążyna based on the sedimentological record and research contamination of trace elements]. Landform Analysis 8, 78-82.

Tobolski, K., 2005. Selected laboratory testing methods. [In:] G. Miotk-Szpiganowicz, K. Tobolski \& J. Zachowicz (Eds): Deposits of the biogenic accumulation reservoirs. Guide-book for laboratory and field activity. Polish Geological Institute, Gdańsk, 68-71.

Tylmann, W., 2005. Lithological and geochemical record of anthropogenic changes in recent sediments of a small and shallow Lake (Lake Pusty Staw, northern Poland). Journal of Palaeolimnology 33, 313-325.

Walanus, A., 2000. Istotność statystyczna wniosków $\mathrm{z}$ analiz ilościowych na przykładzie badań górnego czwartorzędu [The statistical significance of the conslusions of the quantitative analyzes of research on the example of upper Quaternary]. Geologia, Kwartalnik AGH 26, 4, 1-59.

Weckwerth, P., 2010. Evolution of the Torun Basin in the Late Weichselian. Landform Analysis 14, 57-84.

Woszczyk, M., 2011. Paleolimnologiczna interpretacja krzemionki biogenicznej - dyskusja na przykładzie wybranych jezior Niżu Polskiego [Paleolimnology interpretation of biogenic silica - discussion on selected Polish Lowland lakes]. Badania Fizjograficzne, Ser. A, Geografia Fizyczna, 165-179.

Woszczyk, M., 2016. Precipation of calcium carbonate in a shallow polymictic coastal lake: assessing the role of primary production, organic matter degradation and sediment mixing. Oceanological and Hydrobiological Studies 45, 1, 86-99.

Woszczyk, M. \& Spychalski, W., 2007. Czynniki czasowej zmienności zawartości wybranych metali ciężkich w osadach Jeziora Sarbsko (Nizina Gardnieńsko-Łebska) na tle genezy zbiornika [Factors influencing temporal changes in heavy metal contents in the deposits of Lake Sarbsko (Gardno-Łeba Coastal Plain) on the background of the basin evolution]. Ochrona Środowiska i Zasobów Naturalnych 31, 485-497.

Xue, J., Lee, C., Wakeham, S.G. \& Armstrong, R.A., 2011. Using principal components analysis (PCA) with cluster analysis to study the organic geochemistry of sinking particles in the ocean. Organic Geochemistry 42, 4, 356-367.

Zolitschka, B., Behre, K.E. \& Sneider, J., 2003. Human and climatic impact on the environment as derived from colluvial, fluvial and lacustrine archives - examples from the Bronze Age to the Migration Period, Germany. Quaternary Science Reviews 22, 81-100.

Manuscript received 14 October 2015 Revision accepted 20 March 2016 